\title{
Correction: Gastroenterology department operational reorganisation at the time of COVID-19 outbreak: an Italian and Chinese experience
}

Danese S, Ran ZH, Repici A, et al. Gastroenterology department operational reorganisation at the time of COVID-19 outbreak: an Italian and Chinese experience. Gut 2020;69:981-3. doi:10.1136/gutjnl-2020-321143

The correct affiliations for Prof Danese are:

- IBD center, Department of Gastroenterology, Humanitas Clinical and Research CenterIRCCS, Rozzano, Milan, Italy

- Department of Biomedical Sciences, Humanitas University, Pieve Emanuele, Milan, Italy doi:10.1136/gutjnl-2020-321143

This article is made freely available for use in accordance with BMJ's website terms and conditions for the duration of the covid-19 pandemic or until otherwise determined by BMJ. You may use, download and print the article for any lawful, noncommercial purpose (including text and data mining) provided that all copyright notices and trade marks are retained.

(c) Author(s) (or their employer(s)) 2021. No commercial re-use. See rights and permissions. Published by BMJ.

Gut 2021;70:e1. doi:10.1136/gutjnl-2020-321143corr1

A) Check for updates 